\title{
Expression of CD44 and MMP-2: Possible Association with Histopathological Features of Pleuro-Pulmonary Solitary Fibrous Tumors
}

\author{
Plevra-Pulmoner Soliter Fibröz Tümörlerin Histopatolojik \\ Görünümlerinin CD44 ve MMP-2 Ekspresyonu ile Birlikteliği
}

\author{
Funda DEMIRAĞ ${ }^{1}$, Ebru ÇAKIR', Sibel ALPAR ${ }^{2}$, İrfan TAŞTEPE ${ }^{3}$, Sadi KAYA ${ }^{3}$ \\ Departments of ${ }^{1}$ Pathology, ${ }^{2}$ Chest Diseases and ${ }^{3}$ Chest Surgery, M.H. Atatürk Chest Diseases and Chest Surgery Training and Research Hospital, ANKARA, TURKEY
}

\section{ABSTRACT}

Objective: Recent studies have shown that tumor cell adhesion molecules CD44 and matrix metalloproteinases (MMP-2) are expressed strongly in many tumors and associated closely with invasion and metastasis of these tumors. Although solitary fibrous tumors (SFT) have a good prognosis, a minority behave malignantly. The aim of this study was to analyze the correlation between CD44 and MMP-2 expression with histopathological parameters in SFT.

Material and Method: Haemotaxylin-Eosin stained sections of 10 patients with SFT were reexamined for evaluation of histopathological parameters. Immunostaining of CD44 and MMP-2 was performed by using the streptavidin-biotin method with mouse monoclonal antibody.

Results: Our cases consisted of three male and seven female patients with a mean age of 54.5 years. Three patients had a history of asbest exposure. Complete resection was performed in 2 malignant (multiple masses) and 8 benign SFT cases. One intrapulmonary tumor was treated with pneumonectomy. 3 cases originated from the right and 7 from the left hemithorax. Tumor size ranged from 5 to $27 \mathrm{~cm}$. All cases expressed strong CD44. Only 2 malignant SFT and intrapulmonary SFT expressed focal MMP-2.

Conclusion: Although MMP-2 positivity was observed in 2 malignant cases, CD44 positivity was not associated with malignancy criteria in solitary fibrous tumors.

Key Words: Solitary fibrous tumors, Histopathology, CD44, MMP-2
ÖZ

Amaç: Yakın zamanda yapılan araştırmalar, tümör hücre adezyon molekülleri CD44 ve matriks metalloproteinazın (MMP-2) pek çok tümörde kuvvetle eksprese olduğunu ve tümörün invazyonu ve metastazı ile ilişkili olduğunu göstermiştir. Soliter fibröz tümörler (SFT) iyi prognozlu olmakla birlikte, küçük bir kısmı malign tümör gibi davranır. Bu çalışmanın amacı, CD44 ve MMP-2 ekspresyonu ile histopatolojik parametrelerin ilişkisini analiz etmektir.

Gereç ve Yöntem: Soliter fibröz tümörlü 10 hastanın hematoksilen-eozin boyalı kesitleri, histopatolojik parametreleri değerlendirmek için tekrar incelendi. CD44 ve MMP-2 immün boyamaları fare monoklonal antikorları ile streptavidin-biotin yöntemi kullanılarak yapıldı.

Bulgular: Olgularımız yaş ortalaması 54,5 olan 3 erkek ve 7 kadından oluşmaktadır. Üç hastanın asbest maruziyeti öyküsü vardır. Tam rezeksiyon 2 malign (multipl kitleli) ve 8 benign SFT'de yapıldı. İntrapulmoner yerleşimli olan bir tümör pnömonektomi ile tedavi edildi. SFT 3 olguda sağ, 7 olguda ise sol hemitorakstan köken almaktaydı. Tümör çapı 5-27 cm arasında değişmekteydi. Bütün olgular güçlü CD44 eksprese etmekteydi. Bununla beraber yanlıca 2 malign SFT ve intrapulmoner SFT fokal MMP-2 eksprese etmekteydi.

Sonuç: MMP-2 pozitifliği 2 malign olguda gözlenmesine rağmen, CD44 pozitifliği ile soliter fibröz tümördeki malignite kriterleri arasında ilişki saptanmamıştır.

Anahtar Sözcükler: Soliter fibröz tümör, Histopatoloji, CD44, MMP-2 


\section{INTRODUCTION}

Solitary Fibrous Tumor (SFT) is an uncommon soft tissue tumor, initially reported as a pleura-based lesion, but recently described in numerous sites including liver, lung, orbita, nasal passages, skin, thyroid, and gastrointestinal tract (1). A 'patternless pattern' is the characteristic feature of the lesion. Oval or spindle cells are arranged in storiform, fascicular and hemangiopericytomatous patterns. They may contain myxoid, fibrotic and hyalinized areas. All SFT of pleura and extrapleural origin consistently express CD 34 and vimentin. Although most SFT behave in a benign fashion, some recur locally and metastasize. Malignant SFT may be cured by simple excision. The behavior of SFT is unpredictable (2-4).

Recent studies have shown that tumor cell adhesion molecules CD44 and matrix metalloproteinases (MMP-2) are expressed strongly in many tumors and are associated closely with invasion and metastasis. CD44 is a cell surface glycoprotein expressed in lymphocytes, monocytes and granulocytes. CD44 is implicated in cell migration, lymphocyte homing and tumor metastasis (5). MMP-2, among other MMPs, primarily hydrolyzes type IV collagen, the major structural component of basement membrane. Numerous studies have shown that MMP-2 is overexpressed in various human cancers and is implicated in tumor initiation, invasion, angiogenesis and metastasis (6). The aim of this study was to analyze the correlation of CD44 and MMP-2 expression with histopathological parameters in pleuro-pulmonary SFT.

\section{MATERIAL and METHOD}

We reviewed 10 patients who had undergone surgical resection for benign or malignant SFT. Clinical findings and follow-up information were obtained for all patients from clinical cards or directly from the patients' families. Haemotoxylin-Eosin stained sections were reexamined for evaluation of histopathological parameters (degree of cellularity, keloid type collagen deposition, perivascular hyalinization, hemangiopericytoma-like area, nuclear pleomorphism, number of mitoses, necrosis, cyst formation, and myxoid changes).

The cases were classified as benign or malignant according to criteria reported by England at al. as follows: mitotic count more than four mitoses per 10 high power field (HPF), tumour necrosis, hypercellularity, and nuclear atypia (7). The cases were staged according to the de Perrot scheme (from stages 0 to 4$)(6,8)$. All cases were stained immunohistochemically with CD34, calretinin and cytokeratin 5/6 (Neomarker prediluted). Immunostaining of CD44 (CD44Std/HCAM Ab-4, Neomarker prediluted) and MMP-2 (Neomarker prediluted) was performed using streptavidin-biotin method with mouse monoclonal antibody. Sections of $6 \mu$ were cut from formalin-fixed, paraffin-embedded tissue specimens and mounted on poly-l-lysine coated slides that were dewaxed by xylene, rehydrated, and finally washed in phosphate buffer ( $\mathrm{pH} 7.6)$ for 10 minutes. CD44 required epitope retrieval in 0.01 $\mathrm{mol} / \mathrm{l}$ citrate buffer for $20 \mathrm{~min}$ in a microwave oven. Immunostaining was performed with the streptavidinbiotin complex kit (Lab Vision). After incubation with the chromogen, sections were counterstained with Harris Hematoxylin and coverslipped. The intensity of CD44 and MMP-2 staining was evaluated by light microscopy.

CD44 was localized in the cell membrane. The expression of CD44 was graded as negative (-), 10\% positive cells (+); $10-50 \%$ positive cells $(++)$; and $>50 \%$ positive cells $(+++)$ (9).

MMP2 was localized in the cytoplasma. The extent of expression was graded as focal (50\% of the cell) or diffuse ( $>50 \%$ of cells) (10).

\section{Statistical Analysis}

Data analysis was performed using SPSS for Windows, version 11.5. Means were compared using Student's $t$ and Mann-Whitney U test was applied for the comparisons of the median values. Nominal data were tested by Fisher's exact test. The degree of association between continuous variables was calculated by Spearman's "rho" correlation coefficient. A $\mathrm{p}$ value less than 0.05 was considered statistically significant.

\section{RESULTS}

10 patients underwent surgical resection for 8 benign and 2 malignant SFT. There were 3 male (30\%) and 7 female (70\%) patients with a mean age of $54.5 \pm 11.6$ (range 30-71 years). Three patients with 2 malignant SFT and 1 benign SFT had a history of asbestos exposure. The case with intrapulmonary benign SFT was from the Cappadocia area which had erionite exposure. This patient had hemoptysis and cough. Tumor was observed in broncoscopic biopsy (Figure 1). Two patients with malignant SFT complained of progressive dyspnea, cough, back pain and weight loss. Pleural effusion was observed in two malignant SFT cases. The pleural effusion was serous and exudative. Cytologic examination revealed benign features. Pleural needle biopsy did not reveal an accurate diagnosis in two malignant SFT cases. Seven cases had incidental findings. A history of smoking was present in three male patients. Transthoracic biopsy was performed for preoperative pathologic diagnosis in one case. 
Complete resection was performed in all cases. 9 cases had tumor arising from pleura (3 from the visceral and 6 from the parietal pleura). Left pneumonectomy was performed for one intrapulmonary tumor. Three cases (30\%) originated from the right and $7(70 \%)$ from the left hemithorax. 2 malign SFT cases had multiple masses and were localized in the left hemithorax. According to the de Perrot staging scheme, 5 cases (50\%) were stage 0 , whereas 3 cases were stage 1 , and 2 cases were stage 4 . Tumor size ranged from 5 to $27 \mathrm{~cm}$ (mean $15.5 \mathrm{~cm}$ ) (Table I). Tumor diameter of malignant SFT cases was higher than benign SFT ( $p=0.044)$. Tumor diameter of SFT in female patients were significantly higher than male patients $(\mathrm{p}=0.033)$. The diameter of the tumors localized in visceral pleura and lung were higher than those localized in the parietal pleura $(\mathrm{p}=0.038)$.

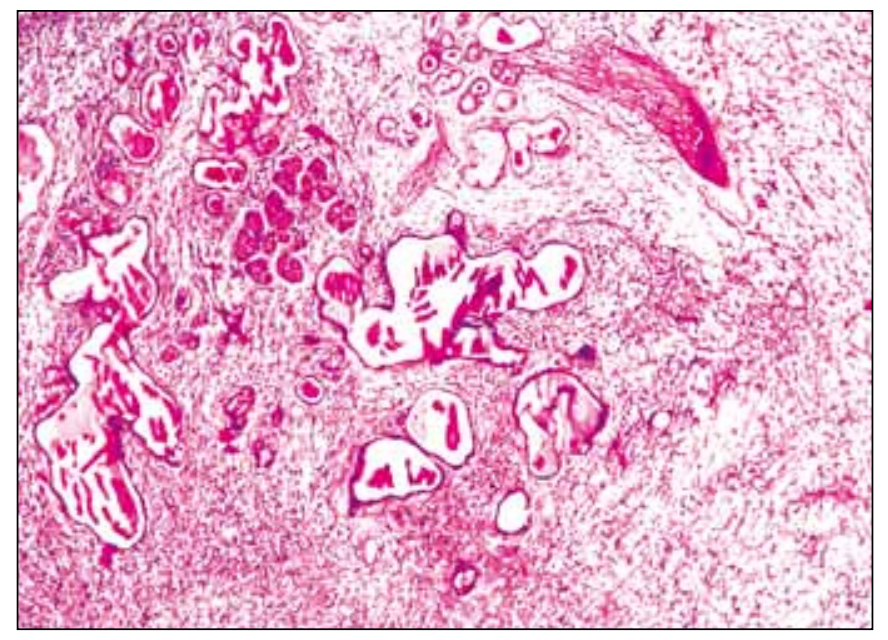

Figure 1: SFT infiltrating the bronchial wall (H\&E; x400).

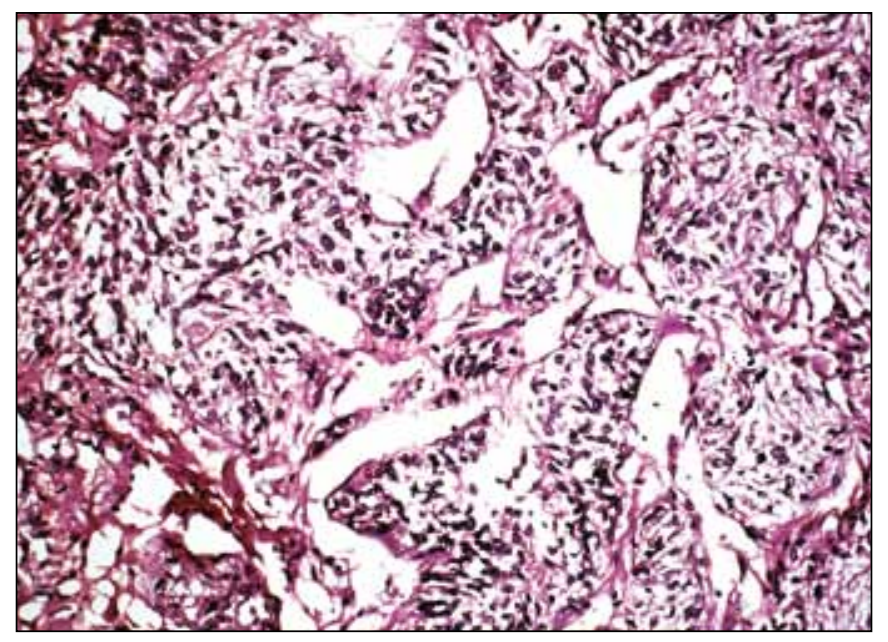

Figure 3: Hemangiopericytoma-like area (H\&E; x400).
Malign SFT cases showed pleomorphism, $>4$ mitoses/10 HPF and tumor necrosis. Keloid type collagen, hypocellular and hypercellular areas were observed in all cases (Figure 2). Only one benign SFT had no keloid type collagen. Perivascular hyalinization was not observed in 5 benign SFT cases. Only one malignant SFT and 3 benign SFT cases contained a hemangiopericytoma-like area (Figure 3). One malignant SFT and 2 benign SFT cases showed myxoid changes, whereas 6 ( 2 malignant SFT and 4 benign SFT) patients had cyst formation (Figure 4). Nuclear pleomorphism was observed only in two malignant SFT cases. Multiple tumor masses, pleomorphism and high mitotic activity (more than four mitotic figures per 10 HPF) were observed in malignant SFT (Figure 5). Tumor necrosis was observed in 2 malignant SFT cases. All cases expressed strong CD44 in the cell membrane (Figure 6). Only 2 malignant SFT and 1 intrapulmonary SFT cases

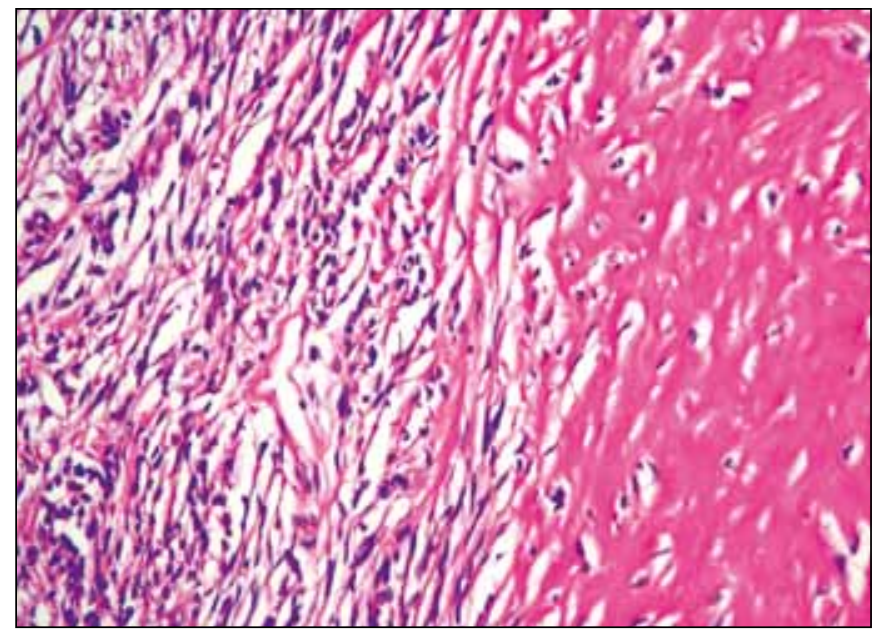

Figure 2: Hypercellular and hypocellular areas (H\&E; x200).

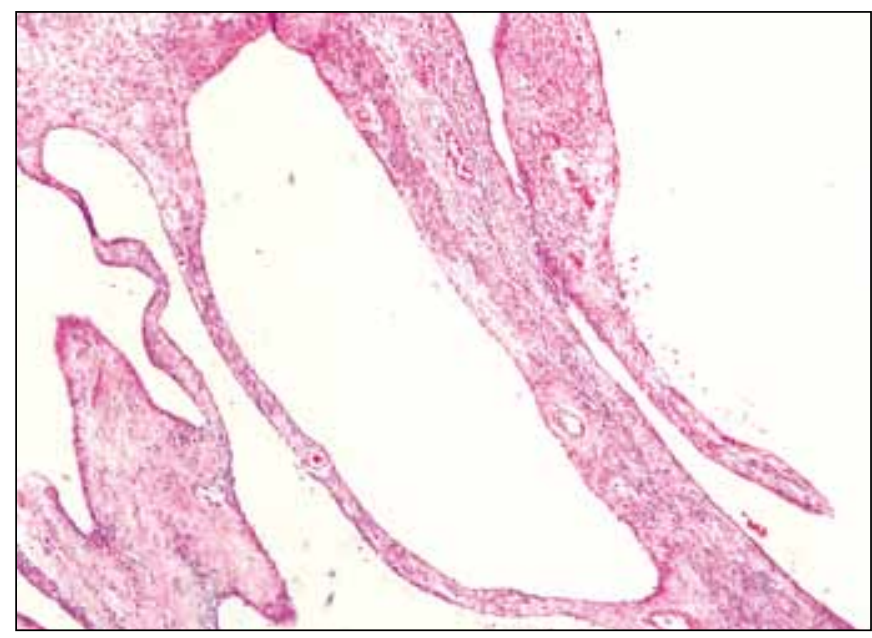

Figure 4: Cyst formation (H\&E; x100). 
expressed focal MMP-2. Endothelial MMP-2 expression was observed in intrapulmonary SFT whereas tumour cells and endothelial cells were positive in 2 malignant SFT cases (Figure 7, 8) (Table II).

The postoperative course was uneventful in 9 cases. The female patient with malignant SFT died from heart failure postoperatively. All cases except one were followed-up for 13-92 (mean 47) months. Squamous cell carcinoma in the right lower lobe was detected in the male patient with malignant SFT 6 years later. He underwent inferior bilobectomy with right thoracotomy. This case was stage T2N1M0. He had chemotherapy and he is alive with no sign of recurrence. Other cases are still alive without recurrence.

\section{DISCUSSION}

Pleural SFT is an uncommon spindle cell mesenchymal tumor. The origin of SFT is controversial. Studies suggested

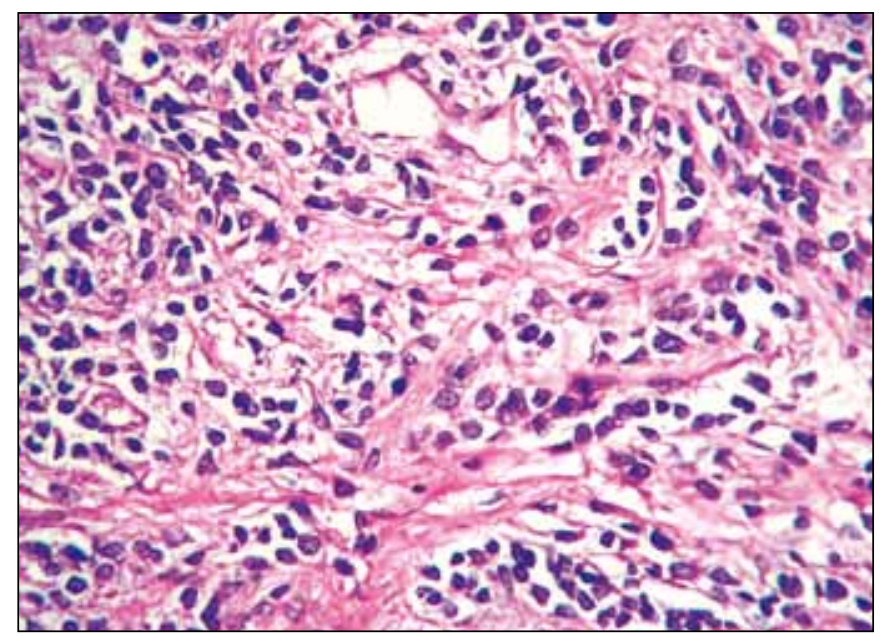

Figure 5: Cellular pleomorphism and mitoses (H\&E; x200).

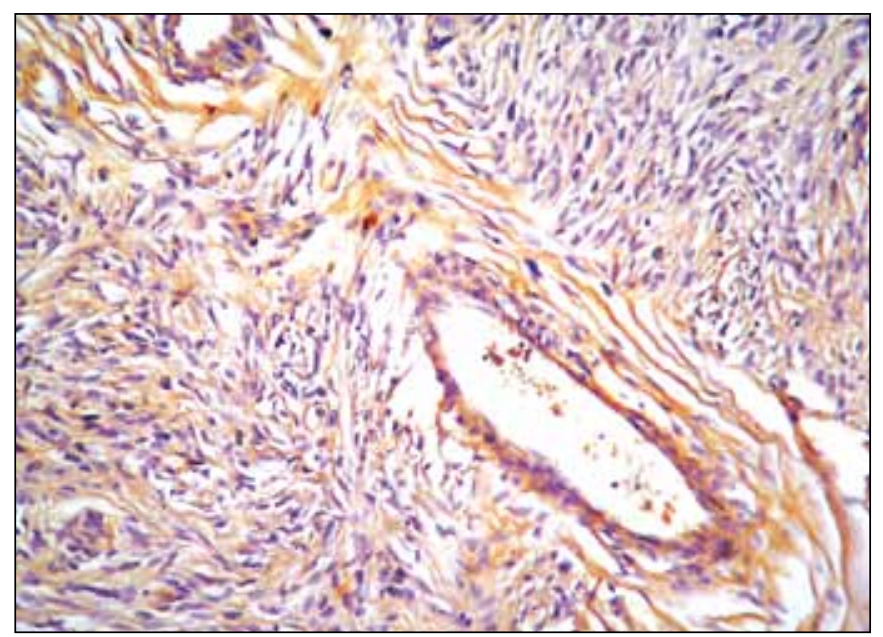

Figure 7: Positive immunostaining for MMP-2 in malignant SFT (MMP-2, x200). that CD34 positive submesothelial interstitial dendritic cells may be the stem cells that give rise to SFT (11). Specific vascular endothelial cell markers, such as VEGFR-1, Tie-2 and c-met have been reported to be expressed in SFT. These findings indicate that most SFT may be closely related to vascular or lymphatic endothelial cells (12).

SFT make up fewer than 5\% of pleural tumors (13). Despite their rarity, it is important to differentiate them preoperatively from malignant localized mesotheliomas. CD34, calretinin and cytokeratin 5/6 immunostaining in addition to gross, histologic and clinical findings are usually effective in distinguishing most pleural spindle cell tumors. In this study, all cases were positive for CD34 but negative for calretinin and cytokeratin 5/6.

We observed female predominance. Most of our cases were in the fourth to sixth decades. This finding is similar

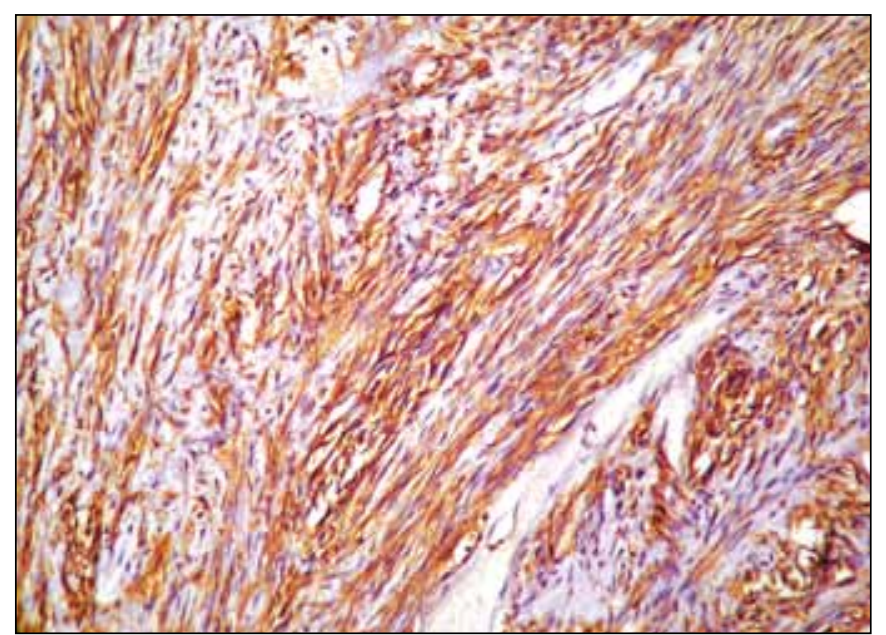

Figure 6: Diffuse positive membraneous immunostaining for CD44 (CD44, x200).

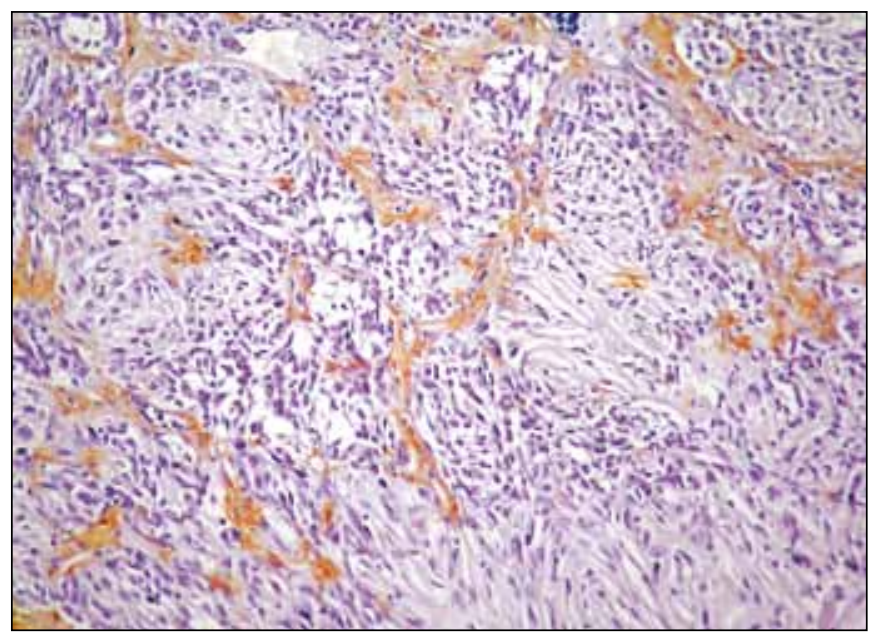

Figure 8: Endothelial immunostaining for MMP-2 in intrapulmonary SFT (MMP-2, x400). 
Table I: Clinical features of 10 SFT cases

\begin{tabular}{|r|c|c|c|c|c|c|}
\hline Case & Age/sex & Asbestos/erionite exposure & Location/site & Tumor size (cm) & Solid/multiple & Follow up (months) \\
\hline 1 & $60 / \mathrm{M}$ & No & RP & 27 & Solid & 92 \\
\hline 2 & $56 / \mathrm{F}$ & Erionite exposure & Left lung & 16 & Solid & 87 \\
\hline 3 & $65 / \mathrm{F}$ & Asbestos exposure & RV & 7 & Solid & 81 \\
\hline 4 & $71 / \mathrm{F}$ & Asbestos exposure & LP & Mean 14 & Multiple & Postoperative ex \\
\hline 5 & $63 / \mathrm{M}$ & Asbestos exposure & LP & Mean 18 & Multiple & 72 \\
\hline 6 & $30 / \mathrm{F}$ & No & LP & 15 & Solid & 51 \\
\hline 7 & $55 / \mathrm{F}$ & No & LP & 21 & Solid & 43 \\
\hline 8 & $48 / \mathrm{M}$ & No & LP & 27 & Solid & 41 \\
\hline 9 & $51 / \mathrm{F}$ & No & RP & 4,5 & Solid & 13 \\
\hline 10 & $46 / \mathrm{F}$ & No & LV & 5 & Solid & 26 \\
\hline
\end{tabular}

R: right, L: left, V: visceral pleura, P: parietal pleura, F: female, $\mathbf{M}:$ male.

Table II: Pathological features of SFT

\begin{tabular}{|c|c|c|c|c|c|c|c|c|c|c|c|}
\hline Case & $\begin{array}{l}\text { Keloid } \\
\text { type } \\
\text { collagen }\end{array}$ & $\begin{array}{l}\text { Perivascular } \\
\text { hyalinisation }\end{array}$ & $\begin{array}{l}\text { Hemangio- } \\
\text { pericytoma } \\
\text { like area }\end{array}$ & $\begin{array}{c}\text { Pleomor- } \\
\text { phism }\end{array}$ & $\begin{array}{c}\text { Mitoses/10 } \\
\text { HPF }\end{array}$ & $\begin{array}{c}\text { Tumor } \\
\text { necrosis }\end{array}$ & Cyst & $\begin{array}{l}\text { Myxoid } \\
\text { changes }\end{array}$ & $\mathbf{B} / \mathbf{M}$ & CD44 & MMP-2 \\
\hline 2 & Yes & No & Yes & No & 2 & No & Yes & No & B & +++ & + \\
\hline 3 & Yes & Yes & No & No & No & No & No & No & B & +++ & +++ \\
\hline 5 & Yes & Yes & Yes & Yes & 5 & Yes & Yes & Yes & M & +++ & - \\
\hline 6 & No & Yes & No & No & No & No & No & No & B & +++ & - \\
\hline 7 & Yes & No & No & No & 1 & No & No & Yes & B & +++ & - \\
\hline 8 & Yes & No & No & No & No & No & Yes & No & B & +++ & - \\
\hline
\end{tabular}

B: benign, M: malignant.

to the literature. Asbestos exposure was not observed in the literature but 3 patients (30\%) in the present study had asbestos exposure. This finding may be explained by the frequency of environmental asbestos exposure in Central Anatolia. It is also interesting that, the case with intrapulmonary SFT is from the Cappadocia area. Intrapulmonary SFT associated with erionite exposure has not been reported previously.

Hypertrophic pulmonary osteoarthropathy and hypoglycemia have been reported with SFT (1). However, these symptoms were not observed in this study.
A definitive diagnosis for intrapulmonary SFT can be made by bronchoscopic biopsy with the help of immunohistochemical assays. Transthoracic fine-needle aspiration biopsy can be a useful diagnostic procedure in unresectable tumors. However, diagnosis of pleural SFT can rarely be achieved before surgical resection (14).

SFT usually presents as a solitary mass. In the present study two malignant SFT cases had multiple masses. The median tumor size was $15.5 \mathrm{~cm}$ (range 5-27 cm). A diameter higher than $10 \mathrm{~cm}$ was related with a lethal course and recurrence (15). A high mitotic index revealed poor prognosis. Neither diameter nor high mitotic count was related with prognosis. 
In our cases, we often observed keloid type collagen, and hypocellular and hypercellular areas. We did not observe any keloid type collagen in one benign SFT case. Nuclear pleomophism was observed in two malignant SFT cases. In 3 benign SFT cases, the mitotic count was higher than 4 . Myxoid changes in SFT are uncommon. In this study, we observed myxoid changes in one benign and 2 malignant SFT cases.

Watanabe et al. reported a case with synchronous malignant SFT of the pleura and adenocarcinoma of the lung (16). We detected pulmonary squamous cell carcinoma with malignant SFT in a male patient 6 years later. He had a history of asbestos exposure and smoking. These are risk factors for lung carcinoma.

Data in the literature show that the de Perrot stratification of SFT is a reliable prognostic indicator (14). In this study, neither England criteria, de Perrot stratification nor histopathological and immunohistochemical findings were related with prognosis.

The best treatment of benign and malignant SFT is complete surgical resection. In our series, complete surgical resection was performed in all cases. Sporadic mutations in platelet-derived growth factor receptor (PDGFR), and immunohistochemically PDGFR and hepatocyte growth factor receptor were detected in SFT (14). Specific inhibitory molecules were suggested in metastatic SFT treatment.

An important matter for discussion is the malignant potential of these tumors because they may recur locally and even metastasize to distant sites $(17,18)$. Malignant SFT was classified according to England criteria but benign SFT may invade the intercostal muscle or may recur as malignant SFT $(2,3)$. Some markers were suggested to be potentially useful to determine the prognosis of SFT. Sun et al. suggested that bFGF and Ki67 were diagnostically relevant for the evaluation of malignant solitary fibrous tumor (19). P53 positivity was observed in malignant PSFT whereas CD34 positivity was low (20). Cytogenetic data on pleural SFT are sparse. A 48,XY, $+8,+8, \operatorname{del}(9)$ (q22q32) karyotype was reported in a case of recurrent malignant SFT (21). The most frequent defects in benign SFT of the pleura were losses on chromosomal arms 13q, 4q and 21q. Significant gains at chromosome 8 and 25q were observed (22). Cytogenetic analyses revealed multiple chromosomal aberrations such as deletions (9) (q21qter) and a marker chromosome ish der (9)(ABL+) in a malignant pleural SFT (23). These findings support that a gene on $9 \mathrm{q} 22$ might be involved in the pathogenesis of SFT.
Adhesion molecules play an important role in tumor metastasis. CD44 is expressed in a wide variety of cell types, including leukocytes, alveolar macrophages, fibroblasts, vascular endothelial cells and various tumor cells. Leukocytes predominantly express $\mathrm{CD} 44 \mathrm{H}$, which is an $80-90 \mathrm{kDa}$ glycoprotein sometimes referred to as the standard form (CD44s) (5). CD44s expression correlates with prognosis of soft tissue sarcomas and therefore may have a pathogenetic role in tumor progression $(9,12$, 24). However, loss of CD44 expression in gastrointestinal stromal tumors was associated with significantly increased tumor size and proliferation (9). The CD44 immunoreactive site in soft tissue sarcomas was dominated by either the cell membrane or the cytoplasm (25). In our analysis, membranous expression was accepted as a positive pattern. All of our cases expressed strong membranous CD44s. Only CD44 with membranous expression may work as an adhesion molecule for tumor metastasis. However this was not different between benign and malignant SFT in the present study.

Matrix metalloproteinases (MMP) are enzymes which perform a homeostatic role in mesenchymal tissue and function in both tumorigenesis and metastasis. MMP are capable of degrading almost all extracellular matrix components with MMP-2 particularly degrading basement membrane type-IV collagen. Despite the importance of MMP activity in carcinomas, little is known about the role of MMP-2 expression in soft tissue sarcomas. MMP2 expression was associated with poor prognosis and less favorable histological grade in soft tissue tumors (26). Roebuck et al. demonstrated endothelial MMP-2 activity as an essential process that supports the requirement for increased substrate supply for an expanding cell population in sarcomas (10). Our results showed that 2 malignant SFT cases with multiple masses and one intrapulmonary SFT case had MMP-2 positivity. Endothelial MMP-2 activity was observed in intrapulmonary SFT.

Our results suggest that CD44 positivity is not associated with England criteria. However, MMP-2 expression is correlated with England criteria.

\section{REFERENCES}

1. Guillou L, Fletcher JA, Fletcher CDM, Mandahl N: Extrapulmonary solitary fibrous tumour and haemangiopericytoma. In: Fletcher CDM, Unni KK, Mertens F. Eds. Pathology and genetics of tumors of soft tissue and bone. Lyon, IARC Press, 2002, 86-90

2. Kanthan R, Torkian B: Recurrent solitary fibrous tumor of the pleura with malignant transformation. Arch Pathol Lab Med 2004, 128:460-464 
3. Nonaka M, Kadokura M, Takaba T: Benign solitary fibrous tumor of the parietal pleura which invaded the intercostal muscle. Lung Cancer 2001, 31:325-329

4. Sung SH, Chang JW, Kim J, Lee KS, Han J, Park SI: Solitary fibrous tumors of the pleura: surgical outcome and clinical course. Ann Thorac Surg 2005, 79:303-307

5. Matsubara Y, Katoh S, Taniguchii H, Oka M, Kadota J, Kohno $S$ : Expression of CD44 variants in lung cancer and its relationship to hyaluronan binding. J Int Med Res 2000, 28:78-90

6. Yu C, Pan K, Xing D, Liang G, Tan W, Zhang L, Lin D: Correlation between a single nucleotide polymorphism in the matrix metalloproteinase- 2 promoter and risk of lung cancer. Cancer Res 2002, 62:6430-6433

7. England DM, Hochholzer L, McCarthy MJ: Localized benign and malignant fibrous tumors of the pleura. A clinicopathologic review of 223 cases. Am J Surg Pathol 1989, 13: 640-658

8. De Perrot M, Fischer S, Bründler MA, Sekine Y, Keshavjee S: Solitary fibrous tumors of the pleura. Ann Thorac Surg 2002, 74: 285-293

9. Hsu KH, Tsai HW, Shan YS, Lin PW: Significance of CD44 expression in gastrointestinal stromal tumors in relation to disease progression and survival. World J Surg 2007, 31:1438-1444

10. Roebuck MM, Helliwell TR, Chaudhry IH, Kalogrianitis S, Carter S, Kemp GJ, Ritchie DA, Jane MJ, Frostick SP: Matrix metalloproteinase expression is related to angiogenesis and histologic grade in spindle cell soft tissue neoplasms of the extremities. Am J Clin Pathol 2005, 123:405-414

11. Bongiovanni M, Viberti L, Pecchioni C, Papotti M, Thonhofer R, Hans Popper H, Sapino A: Steroid hormone receptor in pleural solitary fibrous tumours and CD34+ progenitor stromal cells. J Pathol 2002, 198:252-257

12. Sawada N, Ishiwata T, Naito Z, Maeda S, Sugisaki Y, Asano G: Immunohistochemical localization of endothelial cell markers in solitary fibrous tumor. Pathol Int 2002, 52:769-776

13. Weynand B, Noël H, Goncette L, Noirhomme P, Collard P: Solitary fibrous tumor of the pleura: a report of five cases diagnosed by transthoracic cutting needle biopsy. Chest 1997, 112:1424-1428

14. Schirosi L, Lantuejoul S, Cavazza A, Murer B, Yves Brichon P, Migaldi M, Sartori G, Sgambato A, Rossi G: Pleuropulmonary solitary fibrous tumors: a clinicopathologic, immunohistochemical, and molecular study of 88 cases confirming the prognostic value of de Perrot staging system and p53 expression, and evaluating the role of c-kit, BRAF, PDGFRs (alpha/beta), c-met, and EGFR. Am J Surg Pathol 2008, 32: $1627-1642$
15. Brozzetti S, D’Andrea N, Limiti MR, Pisanelli MC, De Angelis R, Cavallaro A: Clinical behavior of solitary fibrous tumors of the pleura. An immunohistochemical study. Anticancer Res 2000, 20: 4701-4706

16. Watanabe S, Nakamura Y, Sakasegawa K, Kariatsumari K, Yotsumoto D, Sakata R, Gezima K: Synchronous solitary fibrous tumor of the pleura and lung cancer. Anticancer Res 2003, 23: 2881-2884

17. Cardillo G, Facciolo F, Cavazzana AO, Capece G, Gasparri R, Martelli M: Localized (solitary) fibrous tumors of the pleura: an analysis of 55 patients. Ann Thorac Surg 2000, 70:1808-1812

18. De Perrot M, Kurt AM, Robert JH, Borisch B, Spiliopoulos A: Clinical behavior of solitary fibrous tumors of the pleura. Ann Thorac Surg 1999, 67:1456-1459

19. Sun Y, Naito Z, Ishiwata T, Maeda S, Sugisaki Y, Asano G: Basic FGF and Ki-67 proteins useful for immunohistological diagnostic evaluations in malignant solitary fibrous tumor. Pathol Int 2003, 53:284-290

20. Yokoi T, Tsuzuki T, Yatabe Y, Suzuki M, Kurumaya H, Koshikawa T, Kuhara H, Kuroda M, Nakamura N, Nakatani Y, Kakudo K: Solitary fibrous tumour: significance of p53 and CD34 immunoreactivity in its malignant transformation. Histopathology 1998, 31:423-432

21. De Leval L, Defraigne JO, Hermans G, Dôme F, Boniver J, Herens C: Malignant solitary fibrous tumor of the pleura: report of a case with cytogenetic analysis. Virchows Arch 2003, 442: 388-392

22. Krismann M, Adams H, Jaworska M, Müller KM, Johnen G: Patterns of chromosomal imbalances in benign solitary fibrous tumours of the pleura. Virchows Arch 2000, 437:248-255

23. Torres-Olivera FJ, Vargas MT, Torres-Gómez FJ, Trigo I, Díaz M, González-Cámpora R: Cytogenetic, fluorescence in situ hybridization, and immunohistochemistry studies in a malignant pleural solitary fibrous tumor. Cancer Genet Cytogenet 2009, 189:122-126

24. Peiper M, Sato T, Zurakowski D, Eisenberger C, Heinecke A, Hosch S, Knoefel WT: CD44s expression is associated with improved survival in soft tissue sarcoma. Anticancer Res 2004, 24:1053-1056

25. Kahara N, Ozaki T, Doi T, Nishida K, Kawai A, Shibahara M, Inoue H: CD44 expression in soft tissue sarcomas. Virchows Arch 2000, 436:574-578

26. Benassi MS, Gamberi G, Magagnoli G, Molendini L, Ragazzini P, Merli M, Chiesa F, Balladelli A, Manfrini M, Bertoni F, Mercuri M, Picci P: Metalloproteinase expression and prognosis in soft tissue sarcomas. Ann Oncol 2001, 12:75-80 